\title{
DESIGN MODELS OF THE BEARING CAPACITY OF THE SUPPORT SECTIONS OF BASALT-CONCRETE BEAM STRUCTURES
}

\author{
${ }^{1}$ Karpiuk I.A., Ph.D., Associate Professor, \\ irina.carpyuk@gmail.com, ORCID: 0000-0003-3437-5882 \\ ${ }^{1}$ Tselikova A.S., Assistant, \\ tselikovaa93@gmail.com, ORCID: 0000-0002-1394-3986 \\ ${ }^{1}$ Karpiuk V.M., Doctor of Technical Sciences, Professor, \\ karpiukvim@gmail.com, ORCID: 0000-0002-4088-6489 \\ ${ }^{1}$ Khudobych A.A., postgraduate student, \\ khudobycha@gmail.com, ORCID: 0000-0002-5336-599X \\ ${ }^{1}$ Korchevnyi D.S., student, \\ dmitry_pro@ukr.net, ORCID: 0000-0002-7171-9421 \\ ${ }^{1}$ Kravchuk V.G., student, \\ kravchukvadim010995@gmail.com, ORCID: 0000-0002-2586-4978 \\ ${ }^{1}$ Odessa State Academy of Civil Engineering and Architecture \\ st. Didrikhson, 4, Odesa, 65029, Ukraine
}

\begin{abstract}
In the past decade, structures with non-metallic composite reinforcement (FRP) find more and more widespread use in construction practice, especially in buildings and structures for special purposes.

Due to its high strength, resistance to chemical and physical corrosion, dielectric and diamagnetic properties, low weight and low thermal conductivity, FRP is increasingly replacing steel reinforcement. However, the wider use of concrete structures with FRP is constrained by insufficient knowledge of the features of their work, insufficient regulatory support and little experience in operating these facilities.

Practice has shown the promise and economic feasibility of using FRP in road, hydraulic engineering, transport construction, in the construction of bridge spans, treatment facilities, chemical and food industry facilities, and foundations in an aggressive soil environment. At the same time, the prospects for using basalt-plastic reinforcement (BFRP) are primarily due to the low cost of the main raw material, basalt fibers, due to the presence of significant reserves of basalt in the world.

The basic principles of calculation of bending structures reinforced with FRP, in all foreign standards, as well as in the domestic Manual, are the same as for elements with steel reinforcement.

The design models of the bearing capacity of the bearing sections of concrete beams reinforced with BFRP are considered. The bearing capacity of inclined sections of elements with large $\left(a / h_{0}=3\right)$ and medium $\left(a / h_{0}=2\right)$ shear spans should be determined by an inclined crack using variable coefficients $\varphi_{c 2}, \varphi_{c 3}, \varphi_{c 4}$, taking into account the real length of a dangerous inclined crack $l_{c r f l}^{\prime}$, a significant reduction in tensile stresses in transverse reinforcement to $(0,10-0,15) f_{f k}$. The bearing capacity of the support sections with small $\left(a \leq h_{0}\right)$ shear spans must be determined as for short cantilevers along an inclined compressed strip between the concentrated force and the support using a variable coefficient $k_{f}$. This approach provides satisfactory convergence between the calculated and experimental values of the bearing capacity of inclined sections (coefficient of variation $(v=7,9 \%)$ BFRP.
\end{abstract}

Keywords: basalt-plastic reinforcement BFRP, load-bearing capacity, support section, inclined section, shear span, coefficient, design model, dangerous inclined crack, compressed strip.

Introduction. Practice has shown the viability and economic feasibility of using non-metallic composite reinforcement (FRP) in road, hydraulic, transport construction in the construction of bridge 
girders, sewage treatment plants, chemical and food industries, as well as special purpose buildings and foundations in aggressive soil environments. At the same time, the possibilities for the use of basaltplastic reinforcement (BFRP) are due to the low cost of the main raw material - basalt fibers due to the presence of significant reserves of basalt in the world, as well as their unique physical and chemical properties. In particular, electrical and radio transparency, improved compared to fiberglass reinforcement, chemical resistance to aggressive environments. However, the introduction of FRPreinforced concrete structures into construction practice is constrained by the lack of an appropriate regulatory framework. Therefore, research to improve existing and develop new methods for calculating concrete structures reinforced with BFRP are important and relevant.

Analysis of recent sources of publications. Comparison of experimental data $[1,2]$ with the results of calculations [3] of load-bearing capacity of inclined sections of structures with FRP according to European EUROCODE-2 [4], Japanese JSCE [5], American ACI [6], Canadian CSA [7], Italian CNR [8] design standards showed unsatisfactory convergence (coefficients of variation $(v=59-85 \%)$ because they are based not on real physical schemes of such structures, but on the classical model of truss analogy W.Rittier - E.Mörch and its various modifications, arched analogy or a combination of truss and arched analogies.

Advantageously, in this respect, differs the method of limiting efforts found by O.S. Zalesov and O.F. Ilyin in the edition of SNiP [9], which provides satisfactory convergence $(\mathrm{v}=17,5 \%)$ for experimental reinforced concrete beams [10].

The purpose of the work - is to improve the existing calculation models of bearing capacity of the supporting sections of concrete girder structures with non-metallic composite reinforcement.

Research methods. For predictive estimates of the bearing capacity of the experimental elements before the laboratory tests were carried out modeling of their stress-strain state in the tested PC "Lira-CAD". Experimental tests of concrete beams reinforced with BFRP and manufactured in accordance with the theory of planning according to the three-factor, three-level plan of Box-Benkin B3, under static action of transverse loading using modern measuring equipment. The experimental data were compared with the results of calculations based on the recommendations of existing national design standards and author's methods. For further improvement, those calculation schemes were chosen that provided the best convergence of the experimental and calculated values of the bearing capacity of the experimental elements.

Basic material and results. As shown by the comparison $[3,9,11]$, the experimental and calculated values of the load-bearing capacity of the inclined sections of the experimental reinforced concrete and concrete beams reinforced with BFRP, have, in general, unsatisfactory convergence. Coefficients of variation range from $17.5 \%$ (method of O.S. Zalesov, O.F. Ilyin, Y.A. Klimov in the edition of SNiP 2.03.01-84*) to 85.2\% (Eurocode 2). These differences are presented graphically in the form of the influence of design factors on the bearing capacity of inclined sections of reinforced concrete beams and concrete elements with BFRP.

As can be seen from Fig. 1, the previously valid SNiP 2.03.01-84*, which was based on the experimentally provided physical picture of the run-down reinforced concrete structures, is better consistent with the available experimental data ASD [12] than European standards EN [13], which are based on a modified truss analogy.

Experimental data of A. Tselikova on research of bearing capacity of the concrete beams reinforced by BFRP $[2,3]$, badly agree with results of calculations according to foreign norms, coefficients of variation $(v=59-85,2 \%)$. The influence of the relative span of the cut $a / h_{0}$ is especially inadequately reflected in them. It is obvious that the modified truss analogy or the modified theory of compression fields, on which foreign norms are based, cannot serve as adequate calculation schemes for determining the bearing capacity of inclined sections of beam basalt concrete structures.

Features of calculation of bearing capacity of inclined sections of basalt concrete beams. Taking into account the recommendations of O.S. Zalesov and O.F. Ilyin in the edition of SNiP [9], the calculation of concrete beams reinforced in sufficient quantities $\left(\rho_{f w} \geq 0,0025, \rho_{l f} \geq 0,0100\right)$ with 
basaltoplastic reinforcement BFRP (Fig. 1), on the combined action of transverse force and bending moment to ensure their load-bearing capacity on an inclined crack should be carried out on the most dangerous inclined section:

$$
V_{f} \leq V_{f c}+V_{f w}+V_{f, i n c},
$$

where $V_{f c}, V_{f w} i V_{f, i n c}$ - components of transverse force, which are perceived, respectively, by concrete, transverse basalt-plastic reinforcement and bends.

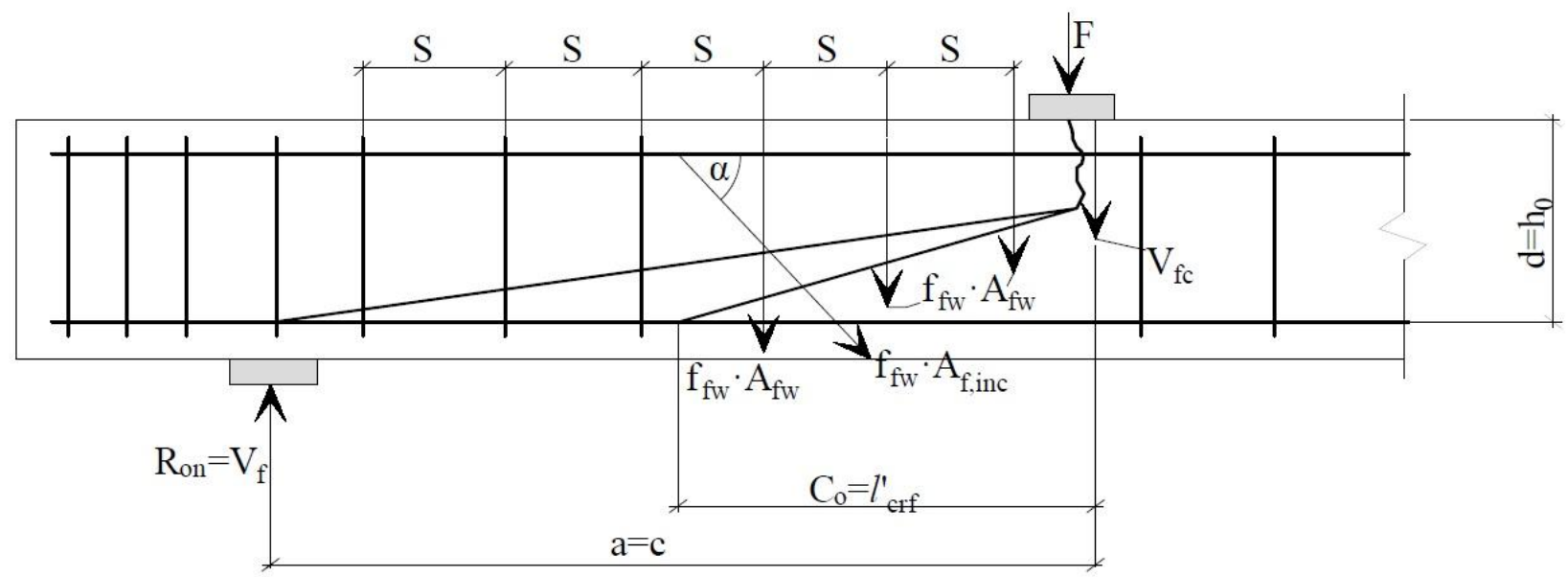

Fig. 1. The calculated scheme of the supporting section of the basalt concrete beam in the determination its bearing capacity under the action of transverse force and bending moment

The transverse force $V_{f}$ in condition (1) is determined from the external load located on one side of the inclined section under consideration.

The component of the transverse force, which is perceived by the concrete of the compressed zone is determined by the improved formula worked out by O.S. Zalesov and O.F. Ilyina:

$$
V_{f c}=\frac{\varphi_{c 2}\left(1+\varphi_{f}+\varphi_{n}\right) f_{c t d} \cdot b_{w} \cdot d^{2}}{a},
$$

where $a=c-$ the length of the projection of the most dangerous inclined section on the longitudinal axis of the element (slice span);

$\varphi_{c 2}-$ coefficient that comprehensively takes into account the influence of the size of the span of the cut, the class of concrete and the number of transverse reinforcement BFRP. This coefficient, in contrast to its prototype $\varphi_{b 2}=2$ in $\mathrm{SNiP}$ [9] for heavy concrete, differentiates the influence of design factors on the value of $V_{f c}$. The coefficient $\varphi_{c 2}$ is obtained experimentally from the inverse. That is, having experimentally established adequate values of the projection length of the dangerous inclined crack $l_{c r f}^{\prime}=C_{0}$ (experimental-statistical dependence (3), as well as confirmed by direct measurements of deformations $\varepsilon_{f w}$ and modeling of VAT stress $\sigma_{f w}$ in the rods of transverse reinforcement, reliable values of components $V_{f w}$ were determined). And the components $V_{f c}=V_{f}^{e x p}-V_{f w}$. In this case, $V_{f, i n c}=0$ because the bends in the beams were absent.

Experimental-statistical dependence of the projection length of a dangerous inclined crack can be represented by:

$$
\hat{Y}\left(l_{c r f l}\right)=176+25 X_{1}+9 X_{2}-16 X_{3}-9 X_{1}^{2}+8 X_{2}^{2}-9 X_{3}^{2}-9 X_{1} X_{3}, \quad m m \quad, \mathrm{v}=5,4 \%,
$$

Then the experimental-statistical dependence of the variable coefficient $\varphi_{c 2}$ has the form:

$$
\hat{Y}\left(\varphi_{c 2}\right)=1,38-0,25 X_{1}-0,12 X_{2}-0,22 X_{1} X_{3}, \mathrm{v}=5,2 \%,
$$


which after replacing the coded variables with natural values of design factors is converted into the form:

$$
\varphi_{c 2}=1,38-0,25\left(a / h_{0}-2\right)-0,12\left(\frac{C-35 M P a}{15 M P a}\right)-0,22\left(a / h_{0}-2\right)\left(\frac{\rho_{f w}-0,0072}{0,0043}\right) \text {. }
$$

Given the allowable extrapolation of the obtained results, the dependence (5) is valid when changing design factors within the following limits:

- the magnitude of the relative span of the slice, $\left(\right.$ factor $\left.\mathrm{X}_{1}\right), a / h_{0}=1,0-3,3$;

- concrete class, $\left(\mathrm{X}_{2}\right)$, in MPa from $\mathrm{C} 12 / 15$ to $\mathrm{C} 45 / 55$;

- coefficient of transverse reinforcement, $\left(\mathrm{X}_{3}\right), \rho_{f w}=0,0018-0,0126$.

Based on the above and taking into account the available research data, the length of the projection of a dangerous inclined crack in concrete elements reinforced with composite reinforcement, including BFRP, with their static load (series 1) is recommended to determine the experimentalstatistical dependence (3), which after replacing the coded variables with natural values has the form:

$$
\begin{aligned}
& l_{c r f l}^{\prime}=\left[176+25\left(a / h_{0}-2\right)+9\left(\frac{C-35 M P a}{15 M P a}\right)-16\left(\frac{\rho_{f w}-0,0072}{0,0043}\right)-9\left(a / h_{0}-2\right)^{2}+\right. \\
& \left.+8\left(\frac{C-35 M P a}{15 M P a}\right)^{2}-9\left(\frac{\rho_{f w}-0,0072}{0,0043}\right)^{2}-9\left(a / h_{0}-2\right)\left(\frac{\rho_{f w}-0,0072}{0,0043}\right)\right] \mathrm{mm}
\end{aligned}
$$

Dependence (6) is valid when the constructive factors change within the limits indicated for expression (5).

The effort in the transverse reinforcement $V_{f w}$ is traditionally determined by the formula:

$$
V_{f w}=q_{f w} \cdot l_{c r f l}^{\prime},
$$

where $q_{f w}$ - the force in the transverse rods (clamps) per unit length of the element, i.e. the intensity of the transverse reinforcement, is determined by the formula:

$$
q_{f w}=\sigma_{f w} \cdot A_{f w} / S,
$$

where $\sigma_{f w}$ - stresses in the rods of the transverse composite reinforcement, which intersect with a dangerous inclined crack. According to full-scale measurements of deformations and modeling of the stress-strain state in the transverse rods of beam structures with large shear spans $\left(a / h_{0}=3\right)$ is recommended to take $\sigma_{f w}=0,1 f_{f k}$, and in elements with medium shear spans $\left(a / h_{0}=2\right)-\sigma_{f w}=0,15 f_{f k}$. In this case, when used as a transverse reinforcement BFRP relative deformations $\varepsilon_{f w}$ in it before the destruction of the test beams were, respectively, 0.0018 and 0.0028. These data are in good agreement with the recommendations of fib [14-16] to limit the relative deformation of the transverse NCA of $0.20-0.25 \%$.

In beam elements with small shear spans $\left(a / h_{0} \geq 1\right)$, direct measurements and modeling of VAT showed that in the rods of the vertical transverse reinforcement there are compressive stresses, the average value of which in the beams with BFRP reached $-363 M \Pi a \approx-0,45 f_{f k}$. With, $\varepsilon_{f w}=-0,0084$. It is obvious that in such elements there is almost the same probability of destruction of their supporting sections both from the cut of concrete behind an inclined crack $\left(\max \tau_{c x z} \leq f_{c k} / 2\right)$, and behind an inclined compressed strip $\left(\max _{c z}=(1,0-1,5) f_{c k}\right)$.

But, given that the height of the compressed zone of concrete under the concentrated force $F$ applied at the end of the span of the cut, artificially decreases (by $25 \%$ or more), still, there is a probability of destruction of these areas according to the calculation scheme of Fig. 2 with a cut of concrete over the top of a dangerous inclined crack and without taking into account the operation of the transverse reinforcement on them, so $\sigma_{f w}=0$ when $a / h_{0} \approx 1$. 
$A_{f w}$ - the cross-sectional area of the crossbars or clamps in one cross-sectional plane of the element.

Transverse force perceived by the limbs:

$$
V_{f, \text { inc }}=q_{f w, i n c} \cdot l_{c r f l} \cdot
$$

When determining $q_{f w, i n c}$ it is necessary to take into account the angles of inclination $a$ and it is allowed to take the stress in them according to the recommendations [14-16] $\sigma_{f}=0,25 f_{f k}$ with $\varepsilon_{f, i n c}=0,0045$ and provided reliable anchoring of the bends on the supports and spans of the elements. The comparison of experimental data and calculated values of bearing capacity of inclined sections $V_{u f}^{*}$ adapted to concrete elements reinforced with NCA by the calculated model of O.S. Zalesov and O.F. Ilyin [9] showed, in general, their satisfactory convergence. The largest differences between the experimental and calculated values of $V_{u f}^{*}$ were observed in basalt-concrete beams with small spans. To improve the convergence of experimental and predicted values of the bearing capacity of the supporting sections of the beams with small spans of the cut $\left(a \leq h_{0}\right)$, we calculate it according to the recommendations of T.I. Baranova [9, 17] according to the scheme of short consoles, transformed in our case to the form (Fig. 2). The legitimacy of this approach is confirmed by the results of field experiments with the use of distribution plates with width $l_{\text {sup }}$ under concentrated forces and on supports, resulting in artificial reduction of shear span, as well as the results of modeling VAT of concrete and transverse reinforcement, which in all beams with such shear spans.

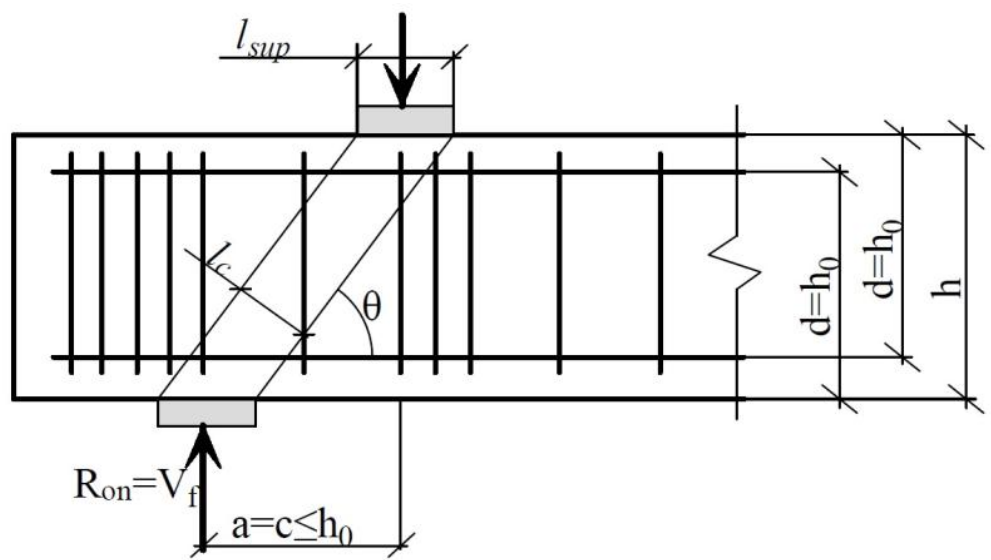

Fig. 2. The calculated scheme of bearing capacity of the supporting section of the basalt concrete beam with a small span of the cut $\left(a \leq h_{0}\right)$ on an inclined compressed strip

The bearing capacity of the compressed inclined strip of the specified element is determined by the condition:

$$
\begin{aligned}
& V_{f} \approx F \leq k_{f} \cdot \varphi_{w 2} \cdot f_{c d} \cdot b \cdot l_{c} \cdot \sin \theta \leq 3,5 f_{c t d} \cdot b \cdot h_{0}, \\
& k_{f} \cdot \varphi_{w 2} \cdot f_{c d} \cdot b \cdot l_{c} \cdot \sin \theta \geq \frac{\varphi_{c 4}\left(1+\varphi_{n}\right) f_{c t d} \cdot b \cdot d^{2}}{a},
\end{aligned}
$$

where $\theta$ - the angle of inclination of the calculated compression strip to the horizontal;

$l_{c}$ - the width of the calculated compression band, which is determined by the formula:

$$
l_{c}=l_{\text {sup }} \cdot \sin \theta \text {, }
$$

where $l_{\text {sup }}$ - the length of the load transfer site along the span of the beam;

$\varphi_{w 2}$ - coefficient that takes into account the effect of transverse rods or clamps, if any, on the height of the beam and is determined by the formula:

$$
\varphi_{w 2}=1+5 \alpha \cdot \mu_{w 1},
$$


where $\alpha=E_{f} / E_{c} ; \mu_{w l}=A_{f w} /\left(b \cdot S_{w}\right)$;

$A_{f w}$ - the cross-sectional area of the clamps in one horizontal plane (if any);

$S_{w}$ - the distance between the specified clamps (if any) on the normal to them. At the same time, the clamps horizontal and inclined at an angle no more than $45^{\circ}$ to the horizontal with observance of well-known requirements are considered.

For the presented design of the basalt concrete beam coefficient $\varphi_{w 2}=1+0=1$.

The coefficient $k_{f}$ in the method of T.I. Baranova $[9,17]$ is recommended to take a constant and equal to 0.8 . For basalt-concrete beams with a short cut span and short consoles $a<h_{0}$ in the reverse way, the experimental value $k_{f}$ was found in experiments № 5,6,7,8,10 according to the experimental plan according to the formula:

$$
k_{f}=V_{u f} /\left(\varphi_{w 2} \cdot f_{c k} \cdot b \cdot l_{c} \cdot \sin \theta\right)
$$

subject to conditions (10).

Processing of the obtained values of the coefficient $k_{f}$ allowed to obtain an adequate experimental and statistical dependence for these elements:

$$
\hat{Y}\left(k_{f}\right)=1,67-0,25 X_{2}-0,21 X_{3}-0,08 X_{2} X_{3}, v=2,5 \%,
$$

replacement of coded variables, in which the natural values of structural factors in the field experiment allows to obtain an empirical formula for determining the coefficient $k_{f}$ taking into account the change of concrete class from C12 / 15 to C45 / 55 and the coefficient of transverse reinforcement within $\mathrm{x}\left(\rho_{f w}=0,0018-0,0126\right)$ :

$$
k_{f}=1,67-0,25\left(\frac{C-35 M P a}{15 M P a}\right)-0,21\left(\frac{\rho_{f w}-0,0072}{0,0043}\right)-0,08\left(\frac{C-35 M P a}{15 M P a}\right)\left(\frac{\rho_{f w}-0,0072}{0,0043}\right) .
$$

Geometric interpretation of the dependence of the coefficient $k_{f}$ on the ratio of design factors is presented in Fig. 3.

The application of experimentally established coefficient $\varphi_{c 2}$ for basalt-concrete beams with large $\left(a / h_{0}=3\right)$ and medium $\left(a / h_{0}=2\right)$, as well as the coefficient $k_{f}$ in elements with small $\left(a / h_{0}=1\right)$ shear spans allowed to bring the experimental and calculated by the above formulas values of bearing capacity of their support sections $V_{u f}$ to satisfactory limits $(v=7,9 \%)$.

The calculation of concrete T-shaped and I-beam concrete beams reinforced with basaltplastic reinforcement, with the combined action of transverse force and bending moment is performed to ensure the strength of inclined strips between inclined cracks in their walls on the supporting sections of the condition:

$$
V_{f} \approx F \leq 0,3 \varphi_{w 1} \cdot \varphi_{c l} \cdot f_{c d} \cdot b_{w} \cdot d,
$$

where $\varphi_{w l}-$ a coefficient that takes into account the influence of normal to the longitudinal axis of the transverse rods or clamps on the bearing capacity of the supporting sections of these beams. It is recommended to determine by formula (12) and take no more than 1.1;

$b_{w}$ - wall thickness of T-shaped or I-beam sections.

It is recommended to determine the coefficient $\varphi_{c 1}$ according to the method of SNiP [9] with the adjusted value of the coefficient $\beta^{*}$ :

$$
\varphi_{c l}=1-\beta^{*} \cdot f_{c d}
$$

where $\beta^{*}=\frac{\varphi_{c 2}}{\varphi_{b 2}} \beta$

$\varphi_{b 2}$ and $\beta$ - coefficients from SNiP [9], which for heavy concrete are equal to 2 and 0.01 , respectively. 


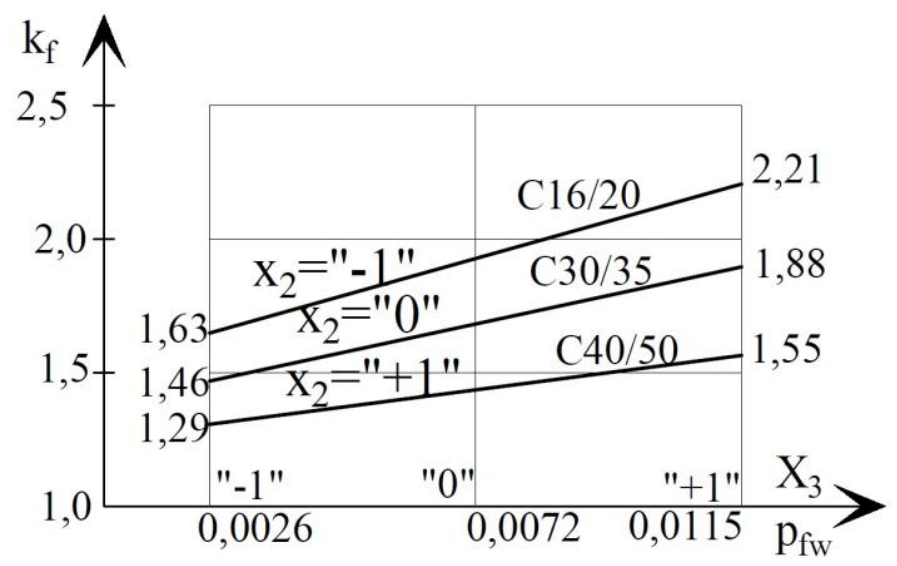

Fig. 3. The influence of concrete class and the number of transverse reinforcement on the value of the variable factor $k_{f}$ in the formula (10)

The bearing capacity of the supporting sections of T-shaped and I-beam basalt-concrete beams is recommended to be determined by inclined strips between inclined cracks with limitation of the coefficient value $\varphi_{w l} \leq 1,1$ and application of the actual thickness of their wall $b_{w}$.

\section{Conclusions:}

1. Comparative analysis of the actual load-bearing capacity of inclined sections of reinforced concrete experimental beams (series ASD) with similar design factors and the use of steel longitudinal and transverse reinforcement instead of basalt-plastic and its calculated values according to the method of O.S. Zalesov and his students in the edition of SNiP 2.03.01-84* [9] and current in Ukraine Eurocode-2 [4] in the form of DSTU BV.2.6-156:2010 [13] showed that the former domestic SNiP [9] provides much better convergence (coefficient of variation $(\mathrm{U}=17,5 \%)$ compared to Eurocode-2 [4] $(v=64,4 \%)$ because it is better than European and other, as studies have shown $[10,11]$, foreign standards reflect the physical picture of the experimental beams under load.

2. Comparison of the actual load-bearing capacity of inclined sections of basalt concrete beams reinforced with BFRP, and its calculated values, calculated according to the recommendations of design standards of foreign countries, also showed their unsatisfactory convergence: the coefficient of variation according to Eurocode 2 [4] was $v=85,2 \%$, Japanese standards JSCE [5] $-v=77,9 \%$, American ACI [6] $-v=81,7 \%$, Canadian CSA [7] $-v=61,1 \%$, Italian CNR [8] $-v=59 \%$. In general, these standards underestimate several times the actual load-bearing capacity of experimental beams reinforced with both steel and basalt-plastic reinforcement. This comparison showed that the best convergence of these values is characteristic of those norms that are not based on a modified truss analogy or a modified theory of compression fields, but on experimentally confirmed and improved calculation schemes of O.S. Zalesov, O.F. Ilyin, T.I. Baranova and others, which better reflect the physical picture of the experimental elements under load.

3 . The bearing capacity of inclined sections of basalt concrete beams with large $\left(a / h_{0}=3\right)$ and medium $\left(a / h_{0}=2\right)$ spans should be determined by the inclined crack using variable coefficients $\varphi_{c 2}, \varphi_{c 3}, \varphi_{c 4}$, taking into account the actual length of the dangerous inclined crack $l_{c r f l}^{\prime}$ and a significant reduction in tensile stresses (till $\left.(0,10-0,15) f_{f k}\right)$ in the transverse reinforcement. The bearing capacity of the supporting sections with small spans of the cut $\left(a \leq h_{0}\right)$ should be determined as for short consoles on an inclined compressed band between the concentrated force and the support using a variable factor $k_{f}$. This approach provides a satisfactory convergence $(v=7,9 \%)$ of the calculated and experimental values of the bearing capacity of the inclined sections of basalt concrete beams of rectangular cross section. 


\section{References}

[1] V. Karpiuk, A. Tselikova, A. Khudobych, I. Karpiuk, A. Kostyuk, "Study of strength, deformability property and crack resistance of beams with BFRP", Eastern-European journal of enterprise technologies, vol. 4/7 (106), pp. 42-53, 2020. https://doi: 10.15587/1729-4061.2020.209378.

[2] I. Rusu, A. Khudobych, A. Tselikova, V. Karpiuk, I. Karpiuk, M. Zavoloka, "Features of stress-strain behaviour of basalt fibre reinforced concrete beam structures", Journal of Engineering Science, vol. XXVII (2), pp. 186-202, 2020. https://doi: 10.5281/zenodo.3949698.

[3] I. Karpiuk, V. Karpiuk, E. Klimenko, A. Tselikova, A. Khudobych, "Comparative analysis of research and calculated values of bearing capacity of reinforced concrete and basalt concrete beams according to recommendations of national design standards", Bulletin of Odessa state academy of civil engineering and architecture, vol. 80, pp. 43-49, 2020. https://doi: 10.31650/2415-377X-2020-80-43-49.

[4] EN 1992-1-1:2004, Eurocode 2. Design of Concrete Structures. Part 1: General rules and rules, CEN, 2004.

[5] JSCE, Recommendation for Design and Construction of Concrete Structures Using Continuous Fiber Reinforcing Materials. Tokyo, Japan: Japan Society of Civil Engineers, 1997.

[6] ACI 440.1R-03, Guide for the Design and Construction of Concrete Reinforced with FRP Bars, American Concrete Institute, 2003.

[7] CAN/CSA-S6-00. Canadian High Bridge Design Code, Canadian Standards Association, 2019.

[8] CNR-DT 203/2006. Guide for the Design and Construction of Concrete Structures Reinforced with Fiber-Reinforced Polymer Bars, Rome, Italy, 2006.

[9] SNiP 2.03.01-84*. Betonnie i jelezobetonnie konstrukcii. Gosstroi SSSR. M.: CITP Gosstroya SSSR, 1989.

[10] V.M. Karpyuk, Yu.A. Somina, A.I. Kostyuk, O.F. Maistrenko, Osoblivosti naprujeno deformovanogo stanu irozrahunku zilizobetonnih konstrukcii za dii ciklichnogo navantajennya visokih rivniv. Monografiya. Odesa: ODABA, 2018.

[11] V. Karpiuk, I. Karpiuk, A. Tselikova, A. Khudobych, "Calculating model of the bearing ability of the substructed areas of baltic basalt concrete structures", Science and education a new dimension. Natural and Technical Science, 2020, vol. VIII (29), pp. 16-22. https://doi: 10.31174/SEND-NT2020-238VIII29-03.

[12] V. Karpiuk, M. Orešković, Yu. Somina, A. Kostiuk, Basis of Force and DeformationForce Resistance of Reinforced Concrete at the Complex Stress-Strain State. Monograph. Varaždin, Croatia, 2019.

[13] DSTU B V.2.6-145-2010. Konstrukciï budinkiv i sporud. Zahist betonnih i zalizobetonnih konstrukcii vid koroziï. Zagalni tehnichni vimogi. K.: Minrehionbud Ukrayiny, 2010.

[14] Fib bul. 55, ModelCode 2010. First complete draft, Lausanne, Switzerland: fib, 2010.

[15] Fib bul.40, FRP reinforcement in RC structures. Technical report TG9.3., Lausanne, Switzrland: fib, 2007.

[16] FIB Bulletin 40: FRP reinforcement in RC structures. International Federation for Structural Concrete, 2007.

[17] T.I. Baranova, A.S. Zalesov, Karkasnosterjnevie raschetnie modeli i injenernie metodi rascheta jelezobetonnih konstrukcii. M.: ASV, 2003. 


\title{
РОЗРАХУНКОВІ МОДЕЛІ НЕСУЧОЇ ЗДАТНОСТІ ПРИОПОРНИХ ДІЛЯНОК БАЛКОВИХ БАЗАЛЬТОБЕТОННИХ КОНСТРУКЦЙ
}

\author{
${ }^{1}$ Карпюк І.А., к.т.н., доцент, \\ irina.carpyuk@gmail.com, ORCID: 0000-0003-3437-5882 \\ ${ }^{1}$ Целікова А.С., асистент, \\ tselikovaa93@gmail.com, ORCID: 0000-0002-1394-3986 \\ ${ }^{1}$ Карпюк В.М., д.т.н., професор, \\ karpiukvim@gmail.com, ORCID: 0000-0002-4088-6489 \\ ${ }^{1}$ Худобич А.O., аспірант, \\ khudobycha@gmail.com, ORCID: 0000-0002-5336-599X \\ ${ }^{1}$ Корчевний Д.С., студент, \\ dmitry_pro@ukr.net, ORCID: 0000-0002-7171-9421 \\ ${ }^{1}$ Кравчук В.Г., студент, \\ kravchukvadim010995@gmail.com, ORCID: 0000-0002-2586-4978 \\ ${ }^{1}$ Одеська державна академія будівництва та архітектури \\ вул. Дідріхсона, 4, м. Одеса, 65029, Україна
}

Анотація. В останні десятиліття все більш широке застосування в практиці будівництва знаходять конструкції з неметалевої композитної арматури (FRP), особливо в будівлях і спорудах спеціального призначення.

Завдяки високій міцності, стійкості до хімічної і фізичної корозії, діелектричним і дімагнетичним властивостями, малій вазі і низькій теплопровідність FRP все частіше замінює сталеву арматуру. Однак, більш широке застосування бетонних конструкцій з FRP стримується недостатньою вивченістю особливостей їх роботи, недостатнім нормативним забезпеченням і невеликим досвідом експлуатації зазначених об'єктів. Практика показала перспективність і економічну доцільність використання FRP в дорожньому, гідротехнічному, транспортному будівництві, при зведенні прогонових будов мостів, очисних споруд, об'єктів хімічної і харчової промисловості, улаштуванні фундаментів в агресивному грунтовому середовищі. При цьому, перспективність використання базальтопластикової арматури (BFRP) обумовлена, перш за все, невисокою вартістю основної сировини-базальтових волокон внаслідок наявності в світі значних запасів базальту.

Основні принципи розрахунку згинальних конструкцій армованих FRP, у зарубіжних нормах, а також вітчизняній Настанові, збережені такими ж, як і для елементів зі сталевою арматурою.

Розглядаються розрахункові моделі несучої здатності приопорних ділянок бетонних балок, армованих BFRP. Несучу здатність похилих перерізів елементів з великими $\left(a / h_{0}=3\right) \mathrm{i}$ середніми $\left(a / h_{0}=2\right)$ прольотами зрізу слід визначати за похилою тріщиною із застосуванням змінних коефіцієнтів $\varphi_{c 2}, \varphi_{c 3}, \varphi_{c 4}$, урахуванням реальної довжини небезпечної похилої тріщини, істотного зменшення розтягуючих напружень, в поперечній арматурі до $(0,10-0,15) f_{f k}$. Несучу здатність приопорних ділянок з малими $\left(a \leq h_{0}\right)$ прольотами зрізу необхідно визначати як для коротких консолей за похилою стислою смугою між зосередженої силою і опорою 3 використанням змінного коефіцієнта $k_{f}$. Такий підхід забезпечує задовільну збіжність розрахункових і експериментальних значень несучої здатності похилих перерізів (коефіцієнт варіації бетонних балок, армованих $(v=7,9 \%)$ BFRP.

Ключові слова: базальтопластикова арматура BFRP, несуча здатність, приопорна ділянка, похилий переріз, проліт зрізу, розрахункова модель, небезпечна похила тріщина, стисла смуга. 


\title{
РАСЧЕТНЫЕ МОДЕЛИ НЕСУЩЕЙ СПОСОБНОСТИ ПРИОПОРНЫХ УЧАСТКОВ БАЛОЧНЫХ БАЗАЛЬТОБЕТОННЫХ КОНСТРУКЦИЙ
}

\author{
${ }^{1}$ Карпюк И.А., к.Т.н., доцент, \\ irina.carpyuk@gmail.com, ORCID: 0000-0003-3437-5882 \\ ${ }^{1}$ Целикова А.С., ассистент, \\ tselikovaa93@gmail.com, ORCID: 0000-0002-1394-3986 \\ ${ }^{1}$ Карпюк В.М., д.т.Н., профессор, \\ karpiukvim@gmail.com, ORCID: 0000-0002-4088-6489 \\ ${ }^{1}$ Худобич А.А., аспирант, \\ khudobycha@gmail.com, ORCID: 0000-0002-5336-599X \\ ${ }^{1}$ Корчевный Д.С., студент, \\ dmitry_pro@ukr.net, ORCID: 0000-0002-7171-9421 \\ ${ }^{1}$ Кравчук В.Г., студент, \\ kravchukvadim010995@gmail.com, ORCID: 0000-0002-2586-4978 \\ ${ }_{1}^{1}$ Одесская государственная академия строительства и архитектуры \\ ул. Дидрихсона, 4, г. Одесса, 65029, Украина
}

\begin{abstract}
Аннотация. В последнее десятилетия все более широкое применение в практике строительства находят конструкции с неметаллической композитной арматурой (FRP),
\end{abstract} особенно в зданиях и сооружениях специального назначения.

Благодаря высокой прочности, стойкости к химической и физической коррозии, диэлектрическим и диамагнетическим свойствам, малому весу и низкой теплопроводности FRP все чаще заменяет стальную арматуру. Однако, более широкое применение бетонных конструкций с FRP сдерживается недостаточной изученностью особенностей их работы, недостаточным нормативным обеспечением и небольшим опытом эксплуатации указанных объектов. Практика показала перспективность и экономическую целесообразность использования FRP в дорожном, гидротехническом, транспортном строительстве, при возведении пролетных строений мостов, очистных сооружений, объектов химической и пищевой промышленности, обустройстве фундаментов в агрессивной грунтовой среде. При этом, перспективность использования базальтопластиковой арматуры (BFRP) обусловлена, прежде всего, невысокой стоимостью основного сырья-базальтовых волокон вследствие наличия в мире значительных запасов базальта.

Основные принципы расчета изгибаемых конструкций армированных FRP, во всех зарубежных нормах, а также отечественном Наставлении сохранены такими же, как и для элементов со стальной арматурой.

Рассматриваются расчетные модели несущей способности приопорных участков бетонных балок, армированных BFRP. Несущую способность наклонных сечений элементов с большими $\left(a / h_{0}=3\right)$ и средними $\left(a / h_{0}=2\right)$ пролетами среза следует определять по наклонной трещине с применением переменных коэффициентов $\varphi_{c 2}, \varphi_{c 3}, \varphi_{c 4}$, учетом реальной длины опасной наклонной трещины $l_{c r f l}^{\prime}$, существенного уменьшения растягивающих напряжений в поперечной арматуре до $(0,10-0,15) f_{f k}$. Несущую способность приопорных участков с малыми $\left(a \leq h_{0}\right)$ пролетами среза необходимо определять как для коротких консолей по наклонной сжатой полосе между сосредоточенной силой и опорой с использованием переменного коэффициента $k_{f}$. Такой подход обеспечивает удовлетворительную сходимость расчетных и экспериментальных значений несущей способности наклонных сечений (коэффициент вариации $(\mathrm{v}=7,9 \%)$ BFRP.

Ключевые слова: базальтопластиковая арматура BFRP, несущая способность, приопорный участок, наклонное сечение, пролет среза, расчетная модель, опасная наклонная трещина, сжатая полоса.

Стаття надійшла до редакції 26.01.2021 